\title{
Purification and Partial Characterization of Inactive Pyruvate Orthophosphate Dikinase from Dark-treated Maize Leaves
}

\author{
Tatsuo SugIYAma and Hiroshi Iwaki \\ Department of Agricultural Chemistry, School of Agriculture, \\ Shizuoka University, Ohya 836, Shizuoka 422
}

Received February 7, 1977

\begin{abstract}
To elucidate the mechanism of light-activation of pyruvate $\mathbf{P}_{\mathfrak{l}}$ dikinase in maize leaf, the nactive form was purified to homogeneity from dark-treated leaves using an activation system to locate it. The purification procedure included ammonium sulfate-fractionation followed by conventional chromatography.

The homogeneous enzyme after maximal activation had a specific activity comparable to that of the active enzyme obtained from non-dark-treated plants. The enzyme was indistinguishable from the active one in its molecular size and charge and in the amino acid composition of its acid-hydrolysate.
\end{abstract}

An important development in the elucidation of the primary photosynthetic carboxylation in $\mathrm{C}_{4}$ plants was the discovery of pyruvate $P_{1}$ dikinase (EC 2.7.9.1), which is responsible for the generation of phosphoenolpyruvate from pyruvate. ${ }^{1)}$ Slack first reported its lightdependency using the leaves of Amaranthus palmeri (dicotyledonous $\mathrm{C}_{4}$ plant), demonstrating that the enzyme is immediately inactivated when the leaves are shaded and rapidly reactivated upon illumination. ${ }^{2)}$ The activation of the enzyme was further analyzed in our labolatory using maize leaf discs and its linking to light electron transport in photosynthesis was demonstrated based on the action spectrum of its photoactivation and its inhibition by $p$-chlorophenyl dimethylurea. ${ }^{3}$

In parallel to these in vivo studies, Hatch and Slack ${ }^{4}$ succeeded in activating the inactive dikinase without the aid of light in crude extracts of dark-treated maize leaf by supplying $P_{1}$ in addition to thiol. They proposed the possible involvement of a heat-labile factor catalyzing the $\mathrm{P}_{\mathrm{L}}$-dependent reactivation of the inactive form in the presence of thiol. After several attempts the postulated factor was isolated from maize leaves free of dikinase and its proteinaceous nature was established by Sugiyama. ${ }^{5 \text { ? }}$

To gain further insight into this unique photoregulation, we tried to purify the inactive form of the dikinase from dark-treated maize leaves by using the activation system to locate the inactive enzyme. In this report we describe the purification process and partly characterized phisico-chemical properties of the purified inactive form in comparison with those of the active one reported previously. ${ }^{6}{ }^{6}$

\section{MATERIALS AND METHODS}

Plant materials. Maize (Zea mays L. var. Golden Cross Bantam or Golden Cross Bantam T51) was grown in a greenhouse under natural light conditions for 4 to 5 weeks. In winter the minimal temperature was kept at $15^{\circ} \mathrm{C}$ during growth. To prepare the activating factor, plants were grown for about 2 weeks in the greenhouse under the same conditions as noted above except for light intensity. From May to September, the plants were shaded with black net cloth (Kuremona No. 600 , Kurare Co., Ltd.) to reduce natural light intensities by approximately $50 \%$. This shading facilitated the extraction of the factor by causing softening of the plant cell wall. In the other seasons, plants were grown under natural light.

Preparation of activating factor. Activating factor was extracted by the method described previously. ${ }^{4}$ )

Supported by grants from The Agricultural Chemical Society of Japan and the Ministry of Education of Japan.

Abbreviations used: $\mathbf{P}_{\mathrm{i}}$, orthophosphate; DTT, dithiothreitol. 
Laminar tissue $(30 \sim 50 \mathrm{~g})$ obtained from dark-treated maize plants was homogenized in a mortar with quartz sand and 3 volumes of an ice-cold buffer ( $\mathrm{pH} 7.5$ ) consisting of $0.1 \mathrm{M}$ Tris- $\mathrm{HCl}, 10 \mathrm{~mm} \mathrm{MgCl}_{2}, 1 \mathrm{~mm}$ EDTA, $10 \mathrm{~mm} \beta$-mercaptoethanol and $2 \%$ of polyamide powder or polyclar AT. The entire experimental procedure was carried out at $4^{\circ} \mathrm{C}$ unless otherwise specified. After filtration through a layer of muslin and gel filtration through Sephadex G-25 equilibrated with $50 \mathrm{~mm}$ Tris- $\mathrm{HCl}$ ( $\mathrm{pH} 7.5$ ) containing $5 \mathrm{mM} \mathrm{MgCl}_{2}$, $0.1 \mathrm{mM}$ EDTA and $5 \mathrm{~mm}$ mercaptan, the eluate was fractionated with ammonium sulfate (35 to $70 \%$ saturation) and subjected to gel filtration with Sephadex G-200 equilibrated with $50 \mathrm{~mm}$ Tris- $\mathrm{HCl}(\mathrm{pH} 7.5)$ containing $5 \mathrm{mM} \mathrm{MgCl}_{2}, 0.1 \mathrm{mM}$ EDTA, $2 \mathrm{mM}$ DTT, $10 \%$ sorbitol and $0.05 \%$ blue dextran 2000 . The factor, free of dikinase activity, was precipitated from active fractions with $70 \%$-saturated ammonium sulfate and stored at $-20^{\circ} \mathrm{C}$.

In some experiments, the factor was used after ammonium sulfate fractionation ( 30 to $40 \%$-saturation) without gel filtration through Sephadex G-200 and stored as described above. Before use for activation, the precipitate was dissolved in a small amount of the buffer used for gel filtration with Sephadex G-200 and the solution was filtered through Sephadex G-25. Under these conditions, the factor was stable for at least $3 \mathrm{hr}$.

Activation of inactive dikinase. The reaction mixture for measuring the $\mathrm{P}_{1}$-dependent reactivation of the inactive enzyme consisted of $50 \mathrm{~mm}$ Tris- $\mathrm{HCl}$ (pH 7.5) $5 \mathrm{~mm} \mathrm{MgCl}, 0.1 \mathrm{mM}$ EDTA, $2 \mathrm{~mm}$ DTT, $10 \%$ sorbitol, $0.05 \%$ blue dextran $2000,2 \mathrm{mM} \mathrm{KH}_{2} \mathrm{PO}_{4}$ and specified amounts of inactive dikinase and the factor. The mixture lacking $P_{i}$ was used as control. Reaction was started by adding $P_{i}$ and carried out at $22^{\circ} \mathrm{C}$. Dikinase was assayed photochemically or radiochemically as described previously for the direction of phosphoenolpyruvate formation. ${ }^{\mathrm{e}}$ Radiochemical assay was employed for measuring enzyme activity from polyacrylamide gel. Phosphoenolpyruvate carboxylase used as a coupling enzyme was purified by the method described previously. ${ }^{7}$

Disc gel electrophoresis. Polyacrylamide disc gel electrophoresis was carried out as described previously, ${ }^{\text {b) }}$ with 40 $/ \mathrm{g}$ of protein loaded on each gel.

Determination of sedimentation velocity of protein. The purified protein $(2.6 \mathrm{mg} / \mathrm{ml})$ was dialyzed against $50 \mathrm{~mm}$ Tris- $\mathrm{HCl}$ ( $\mathrm{pH} 7.0$ ) containing $5 \mathrm{mM} \mathrm{MgCl}_{2}$, $0.1 \mathrm{~mm}$ EDTA, $2 \mathrm{~mm}$ DTT and $0.1 \mathrm{M} \mathrm{KCl}$. Centrifugations were made at $20^{\circ} \mathrm{C}$ and $47,300 \mathrm{rpm}$ in a Hitachi UCA-1A analytical centrifuge at Nagoya University.

Estimation of molecular weight. One mg each of catalase $(232,000$ daltons), urease $(483,000$ daltons), phosphorylase a $(370,000$ daltons) and ribulose- 1,5 bisphosphate carboxylase ( 515,000 daltons), or $1.5 \mathrm{mg}$ of inactive dikinase were dissolved in the buffer used for sedimentation velocity determination. The protein solutions were applied to a column of Sepharose 6B $(1.5 \times 90 \mathrm{~cm})$ and elution was accomplished with the same buffer at a flow rate of $3 \mathrm{ml}$ per hr at $22^{\circ} \mathrm{C}$. To locate inactive dikinase, activation was carried out in the presence of $20 \mu \mathrm{g}$ of the factor after ammonium sulfate fractionation (30 to $40 \%$-saturation) in a total volume of $150 \mu 1$. Ribulose-1, 5-bisphosphate carboxylase was prepared from spinach leaves as described previously. ${ }^{87}$ The other enzyme markers were commercial products. $K_{\mathrm{AV}}$ values were calculated and the results plotted according to Andrews. ${ }^{9}$

Other methods. The amino acid content was determined as described previously using a Nihon Denshi JLC-5AH amino acid analyzer. ${ }^{10)}$ Protein was determined by the method of Lowry et al, with the use of bovine serum albumin as a standard, ${ }^{113}$

\section{RESULTS AND DISCUSSION}

\section{Purification of inactive dikinase}

To inactivate the dikinase, maize plants grown under full sunlight were placed in darkness at 20 to $25^{\circ} \mathrm{C}$ for $2 \mathrm{hr}$ before extraction. Laminar tissue $(100 \sim 300 \mathrm{~g})$ was prepared from mature leaves and diced into segments ( 5 to $10 \mathrm{~mm}$ width) in darkness under a safety dim light. The segments were suspended in four-volumes of an ice-cold buffer consisting of $0.1 \mathrm{M}$ imidazole- $\mathrm{HCl}$ (pH 7.0) containing $10 \mathrm{mM} \quad \mathrm{MgCl}_{2}, 1 \mathrm{~mm}$ EDTA, $10 \mathrm{~mm} \beta$-mercaptoethanol and $2 \%$ of polyamide powder or polyclar AT, and homogenized under a $\mathrm{N}_{2}$ atmosphere in a Waring blender for 2 to 3 min at a full speed. Subsequent operations were carried out at 22 to $25^{\circ} \mathrm{C}$ unless otherwise noted. After filtration through cheesecloth (4 layers) and centrifugation of the filtrate at $10,000 \mathrm{~g}$ for $5 \mathrm{~min}$, the supernatant was passed through a column of Sephadex G-25 equilibrated with $50 \mathrm{mM}$ Tris- $\mathrm{HCl}(\mathrm{pH} 7.0$ ) containing $10 \mathrm{~mm}$ $\mathrm{MgCl}_{2}, 0.1 \mathrm{mM}$ EDTA and $5 \mathrm{~mm} \beta$-mercaptoethanol. At this step the specific activity of the enzyme was approximately 0.02 unit per $\mathrm{mg}$ of protein. This corresponds to 10 to $20 \%$ of the value obtained from plants kept 


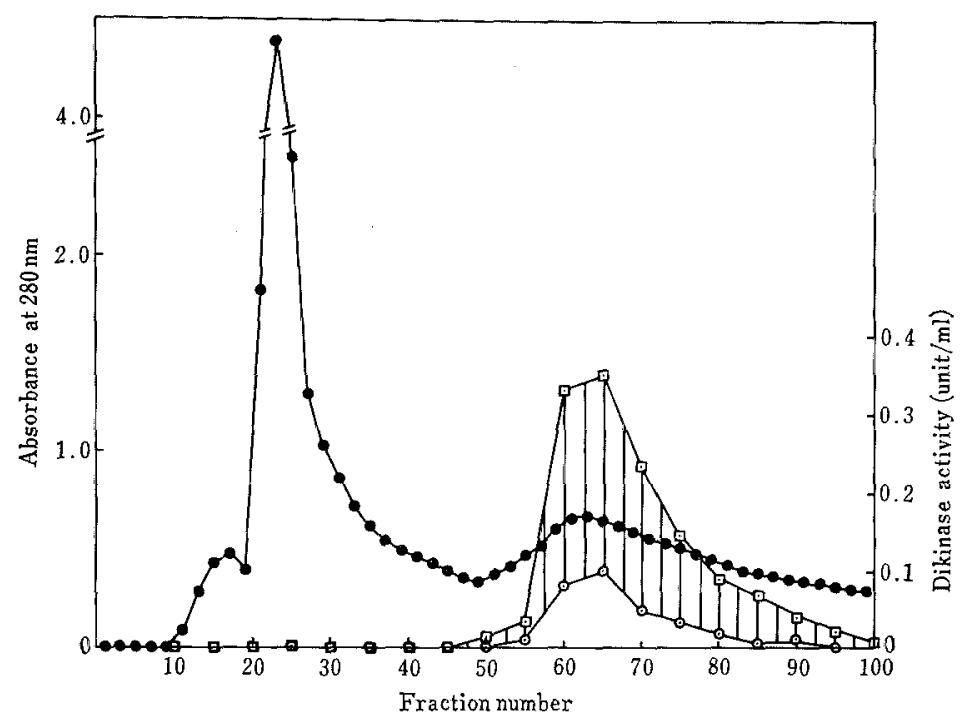

FIG. 1. Chromatogram of Inactive Dikinase on DEAE-Cellulose.

Protein $(176 \mathrm{mg})$ after ammonium sulfate fractionation was applied to a column $(1.5 \times 56 \mathrm{~cm})$ of DEAE-cellulose and $7 \mathrm{ml}$ fractions were collected. Fractions No. $60 \sim 70$ were pooled for the subsequent step. Eighty- $\mu 1$ portions of eluate were activated with $30 \mu \mathrm{g}$ of activating factor from the Sephadex G-200 column.

$\bullet-\bullet, O D$ at $280 \mathrm{~nm} ; \odot-\odot$, dikinase activity at 0 time; $\odot-[\cdot]$, dikinase activity at $2 \mathrm{hr}$ after activation.

continuously under full sunlight, indicating that 80 to $90 \%$ of dikinase was converted to the inactive form by the dark-treatment. Protein in the eluate from gel filtration with Sephadex G-25 was then fractionated with ammonium sulfate ( 40 to $50 \%$-saturation) and stored frozen at $-20^{\circ} \mathrm{C}$ after collecting precipitates by centrifugation.

The precipitate was dissolved in $50 \mathrm{~mm}$ Tris- $\mathrm{HCl}$ (pH 7.0) containing $5 \mathrm{mM} \mathrm{MgCl}_{2}$, $0.1 \mathrm{~mm}$ EDTA and $5 \mathrm{~mm}$ mercaptan and the resulting protein solution was passed through a column of Sephadex G-25 equilibrated with the same buffer. The eluate was applied to a column of DEAE-cellulose equilibrated with the same buffer. After washing the column with one bed volume of $0.12 \mathrm{M} \mathrm{KCl}$ in the buffer, the enzyme was eluted with a 5-bed volume linear $\mathrm{KCl}$ gradient $(0.12 \sim 0.5 \mathrm{M})$. To locate the active and inactive forms of dikinase, a portion of each eluate was incubated with the activating factor in the presence of $2 \mathrm{~mm}$ each of $P_{1}$ and DTT and dikinase was assayed at 0 time and $2 \mathrm{hr}$ after the initiation of the activation reaction. A typical elution pattern from the DEAE-cellulose column is shown in Fig. 1. The most active fractions exhibiting the $P_{\mathrm{i}}$-dependent activation by the factor (shadowed) were collected and the protein was stored at $-20^{\circ} \mathrm{C}$ after precipitating with $70 \%$-saturated ammonium sulfate if necessary.

In some preparations, particularly when samples were stored for a long time after extraction, a minor peak exhibiting the $\mathrm{P}_{\mathrm{i}}$ dependent activation appeared in the eluate washed out with $0.12 \mathrm{M} \mathrm{KCl}$ before the major inactive dikinase fraction. However, dikinase activity was not detected in the preceding fraction from freshly prepared extracts. Thus, it is considered that the minor peak may be due to an artifact in the purification process, presumably due to alteration of the conformation of the inactive form.

The protein from the DEAE-cellulose column was applied to a column of hydroxy- 


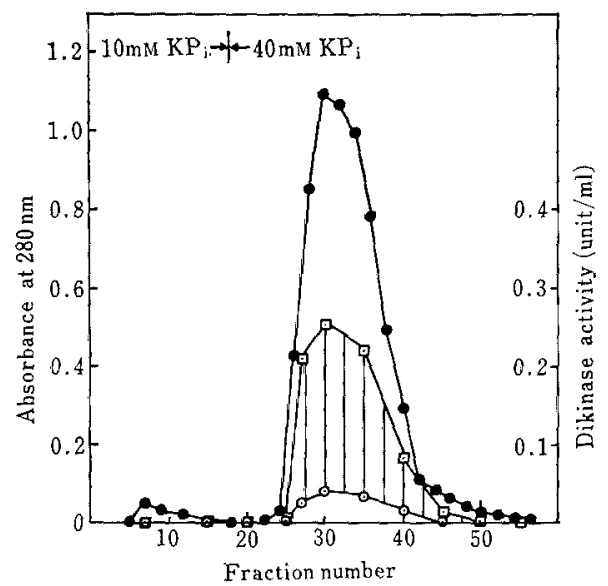

FIG. 2. Chromatogram of Inactive Dikinase on Hydroxylapatite.

Protein $(28 \mathrm{mg}$ ) from the DEAE-cellulose column was applied to a column $(2 \times 4.5 \mathrm{~cm})$ of hydroxylapatite and $2 \mathrm{ml}$ fractions were collected. Fractions No. $28 \sim 40$ were pooled for the subsequent step. Fifty $\mu 1$ portions of eluate were activated with $30 \mu \mathrm{g}$ of activating factor from the Sephadex G-200 column. Symbols are the same as in Fig. 1.

lapatite equilibrated with $10 \mathrm{mM} \mathrm{KH}_{2} \mathrm{PO}_{4-}^{-}$ $\mathrm{K}_{2} \mathrm{HPO}_{4}$ (pH 7.0) containing $5 \mathrm{mM} \mathrm{MgCl}_{2}$, $0.1 \mathrm{~mm}$ EDTA, $5 \mathrm{~mm}$ mercaptan and $10 \%$ glycerol. The column was washed with the buffer, then protein was eluted by raising the concentration of $P_{1}$ to $40 \mathrm{mM}$ in the above buffer, and the inactive and active forms of dikinase were located (Fig. 2). Protein in the fractions of inactive form was collected by centrifugation after precipitating with ammonium sulfate and subjected to gel filtration with Sephadex G-200.

For this, protein was dissolved in $50 \mathrm{~mm}$ Tris- $\mathrm{HCl}$ ( $\mathrm{pH} 7.0$ ) containing $5 \mathrm{mM} \mathrm{MgCl}_{2}$,

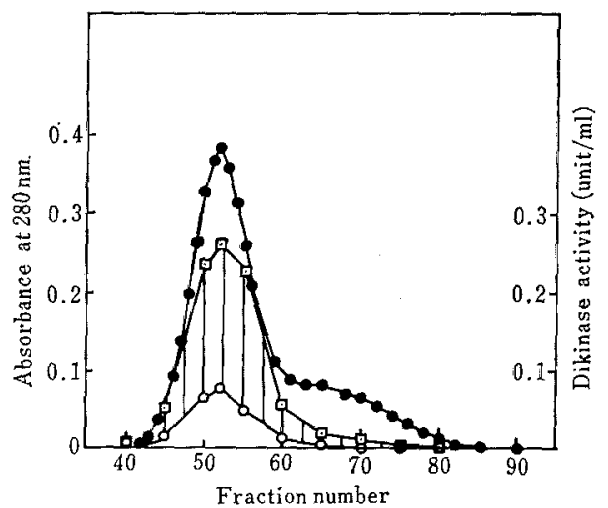

FIG. 3. Gel Filtration of Inactive Dikinase on Sephadex G-200.

Protein $(20 \mathrm{mg}$ ) from the hydroxylapatite column was applied to a column $(2 \times 93 \mathrm{~cm})$ of Sephadex G-200, $3 \mathrm{ml}$ fractions were collected, and fractions No, $46 \sim 55$ were pooled. Activation was conducted as described in the legend of Fig. 2. Symbols are the same as in Fig. 1.

$0.1 \mathrm{~mm}$ EDTA and $2 \mathrm{~mm}$ DTT and applied to a column of Sephadex G-200 equilibrated with the same buffer. Following localization of both forms (Fig. 3), the active fractions of inactive form were pooled, precipitated, and stored as noted earlier. In some cases, the final preparation was stored at $-20^{\circ} \mathrm{C}$ in the presence of $20 \%$ sucrose in the buffer without ammonium sulfate.

A typical flow sheet of the purification process is summarized in Table I. In each step, activation was accomplished by incubating the inactive form with the factor, $P_{1}$ and DTT. A time course analysis of the activation of the final enzyme preparation is shown in Fig. 4. In the mixture lacking either $P_{i}$ or DTT, no activation occurred, The

Table I. Purification of Inactive Dikinase from Dark-treated Maize Leaf

Purification was carried out using $100 \mathrm{~g}$ of laminar tissue.

\begin{tabular}{|c|c|c|c|c|c|}
\hline \multirow[t]{2}{*}{ Step } & \multicolumn{2}{|c|}{ Total activity (units) } & \multirow[t]{2}{*}{ Protein (mg) } & \multicolumn{2}{|c|}{$\begin{array}{r}\text { Specific activity } \\
\text { (units/mg protein) }\end{array}$} \\
\hline & $\begin{array}{c}\text { before } \\
\text { activation }\end{array}$ & $\begin{array}{c}\text { after } \\
\text { activation }\end{array}$ & & $\begin{array}{l}\text { before } \\
\text { activation }\end{array}$ & $\begin{array}{c}\text { after } \\
\text { activation }\end{array}$ \\
\hline Crude extracts & 13.5 & 83.7 & 719 & 0.019 & 0.116 \\
\hline Ammonium sulfate cut & 20.8 & 102.3 & 176 & 0.118 & 0.581 \\
\hline DEAE-cellulose & 3.68 & 109.0 & 28.4 & 0.130 & 3.84 \\
\hline Hydroxylapatite & 1.10 & 50.6 & 19.6 & 0.056 & 2.58 \\
\hline Sephadex G-200 & 0.70 & 30.5 & 10.5 & 0.067 & 2.91 \\
\hline
\end{tabular}




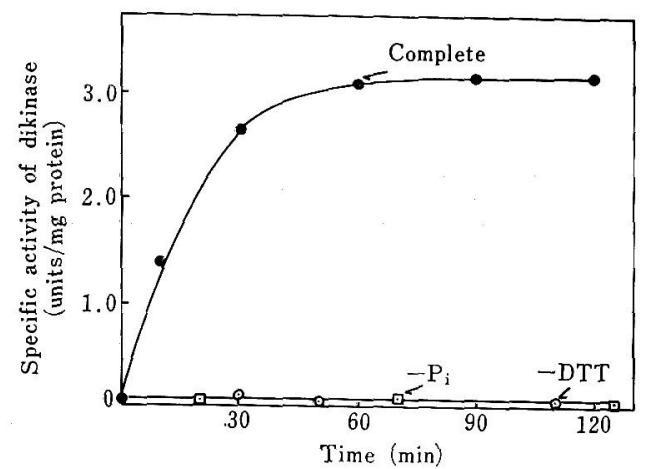

FIG. 4. A Time Course Analysis of Activation of Inactive Dikinase by Activating Factor.

Activation was performed in a mixture containing the factor $(300 \mu \mathrm{g}$ protein) from the Sephadex $\mathrm{G}-200$ column, $20 \mu \mathrm{g}$ of the purified enzyme, and $2 \mathrm{~mm}$ each of $P_{1}$ and DTT in a total volume of $370 \mu \mathrm{l}$. At intervals, $50 \mu 1$ portions of the mixture were taken for photochemical assay of dikinase.

specific activity of the purified form after maximal activation was about 3 units per $\mathrm{mg}$ of protein, which is comparable to that of the purified active form reported previously. ${ }^{6}$ ) The specific activity of the final preparation before activation was about $2 \%$ of that after maximal activation.

\section{Purity of inactive dikinase}

Electrophoresis of the final enzyme preparation on $6 \%$ gel in the presence of $5 \mathrm{mM}$

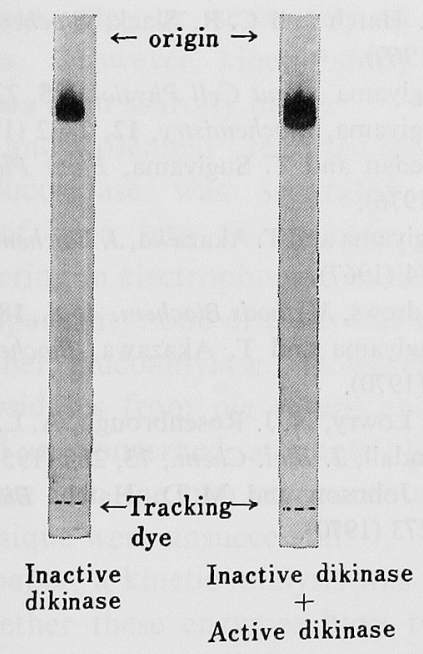

FIG. 5. Polyacrylamide Gel Electrophoretic Patterns of Dikinase.
$\mathrm{MgCl}_{2}$ yielded a single stained protein band with a relative mobility of 0.16 , which coincided with that of the active form as shown in the pattern of coelectrophoresis of the two forms (Fig. 5). A gel slice (5 $\mathrm{mm}$ width) corresponding to the mobility was obtained from the gel before staining and protein was eluted by incubating the slice in $0.3 \mathrm{ml}$ of $50 \mathrm{mM}$ Tris- $\mathrm{HCl}$ buffer (pH 7.0) containing $5 \mathrm{mM} \mathrm{MgCl}_{2}, 0.1 \mathrm{mM}$ EDTA and $5 \mathrm{mM}$ DTT for $18 \mathrm{hr}$ at $22^{\circ} \mathrm{C}$. A $0.1 \mathrm{ml}$ portion of the eluate was then incubated with the factor, DTT and $P_{i}$ for another $2 \mathrm{hr}$ at $22^{\circ} \mathrm{C}$. It was confirmed by detecting the enzyme activity with a radioactive system that the protein exhibits $P_{1}$-dependent activation.

When a homogeneous protein was not obtained on gel electrophoresis, the preparation from gel filtration with Sephadex G-200 was purified further by the method of Jakoby, as described for the active form. ${ }^{6}$ ) The content of dikinase in the leaf apparently depends upon the intensity of the incident light during the growth of plants. The highest content was obtained from plants grown for at least a week under full summer sunlight before harvesting. This is consistent with the report of Johnson et al. who demonstrated the lightdependency of the activity of dikinase in $\mathrm{C}_{4}$ plants over a prolonged period in their growth. ${ }^{12)}$

\section{Molecular properties}

As shown in Fig. 6, the inactive enzyme appears to be monodisperse in sedimentation behavior, having a $s_{20, w}$ of 8.78 which is close to that of the active form (8.86). ${ }^{6)}$ This and the results of electrophoresis indicate that the final preparation is homogeneous.

The molecular weight of the native inactive enzyme was assessed on a Sepharose 6B column calibrated with enzyme markers of known molecular weight, and was found to be identical with that of the native active enzyme ( 370,000 daltons) as shown in Fig. 7.

Amino acid compositions of acid-hydrolysates of the active and inactive forms were determined, and are shown in Table II. The 


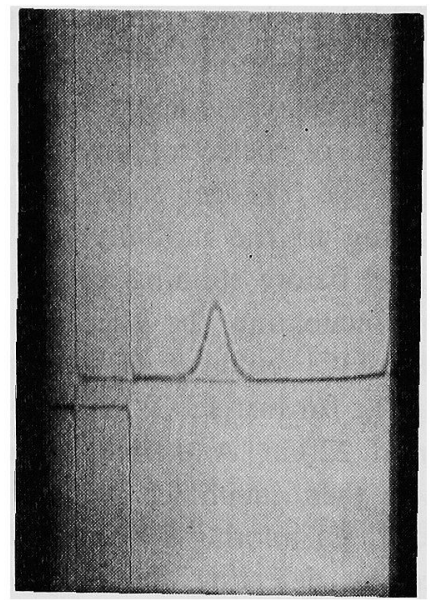

FIG. 6. Sedimentation Pattern of Inactive Dikinase. Photograph was taken 50 min after the centrifuge reached full speed.

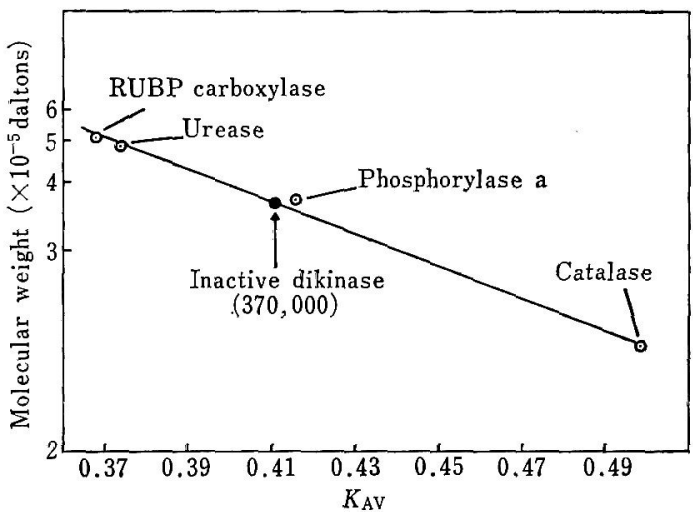

Fig. 7. Estimation of the Molecular Weight of Inactive Dikinase by Gel Filtration.

amino acid compositions of the two forms show no substantial differences.

The data presented in this report demonstrate that the active and inactive forms of maize leaf dikinase have similar physical properties. This eliminates the possibility that interconversion between the forms occurs through dissociation and association of the dikinase molecule. Although further work is necessary to completely characterize these two forms, it is possible that a minor change(s)
Table II. Amino Acid Compositions of Active AND INACTIVE Dikinase

The results are averages of duplicate samples presented as residues per mol protein.

\begin{tabular}{lcc}
\hline Amino acid & Active form & Inactive form \\
\hline Lys & 130.8 & 131.6 \\
His & 48.0 & 45.6 \\
Arg & 142.0 & 134.8 \\
Asp & 246.4 & 237.6 \\
Thr & 126.0 & 122.8 \\
Ser & 115.2 & 116.4 \\
Glu & 332.8 & 327.2 \\
Pro & 169.2 & 165.6 \\
Gly & 279.2 & 265.2 \\
Ala & 268.4 & 264.4 \\
Val & 213.6 & 219.2 \\
Met & 94.0 & 96.0 \\
Ileu & 130.8 & 137.6 \\
Leu & 291.2 & 283.6 \\
Tyr & 60.8 & 61.2 \\
Phe & 114.8 & 107.2 \\
\hline
\end{tabular}

in the inactive form, for example, modification of an amino acid residue, plays a key role in its conversion to the active form.

\section{REFERENCES}

1) M. D. Hatch and C. R. Slack, Arch. Biochem. Biophys., 120, 22 (1967).

2) C. R. Slack, Biochem. Biophys. Res. Commun., 30, 493 (1968).

3) E. Yamamoto, T. Sugiyama and S. Miyachi, Plant Cell Physiol., 15, 987 (1974).

4) M. D. Hatch and C. R. Slack, Biochem. J., 112, 549 (1969).

5) T. Sugiyama, Plant Cell Physiol., 15, 723 (1974).

6) T. Sugiyama, Biochemistry, 12, 2862 (1973).

7) K. Uedan and T. Sugiyama, Plant Physiol., 57, 906 (1976).

8) T. Sugiyama and T. Akazawa, J.Biochem. (Tokyo), 62, 474 (1967).

9) P. Andrews, Methods Biochem. Anal., 18, 1 (1970).

10) T. Sugiyama and T. Akazawa, Biochemistry, 9, 4499 (1970).

11) O. H. Lowry, N. J. Rosenbrough, A. L. Farr and J. Randall, J. Biol. Chem., 73, 265 (1951).

12) H.S. Johnson and M. D. Hatch, Biochem. J., 119, 273 (1970). 